\title{
Нестандартні методи при виконанні малоінвазивних операцій у лікуванні кишкової непрохідності пухлинного генезу
}

\author{
YU. V. HRUBNYK, A. D. NETKOV ${ }^{1}$, O. M. YUZVAK
}

Odesa National Medical University

MI "City Clinical Hospital” № 11

\section{NON-STANDARD METHODS IN PERFORMING OF MINIMALLY INVASIVE SURGERIES IN TREATMENT OF INTESTINAL OBSTRUCTION OF TUMOR GENESIS}

Гостра кишкова непрохідність (ГКН) - синдромна категорія, що об’єднує ускладнення протягом різних за етіологією захворювань і патологічних процесів, які формують морфологічний субстрат ГКН. За даними ВООЗ, ГКН становить 3,8 \% від усіх невідкладних захворювань черевної порожнини. У структурі ГКН розрізняють гостру обтураційну кишкову непрохідність (ГОКН), однією з причин виникнення якої $€$ колоректальний рак $[1,2,6]$. За останні 40 років питома вага ГОКН у структурі всіх форм ГКН збільшилася з 2-5 \% до 20-24 \% [7]. Загальна післяопераційна летальність серед хворих з ГОКН коливається від 21 до 44 \% [4, 5], а післяопераційні запально-гнійні ускладнення при виконанні операції на висоті непрохідності сягають 40 \% [3].

Дану групу хворих госпіталізують, як правило, ургентно у тяжкому стані, і в зв'язку з цим виконують триетапні та двохетапні операційні втручання. Виконання одноетапних операційних втручань $\epsilon$ небезпечним через високий ризик неспроможності швів анастомозів. Ця група хворих потребує проведення інфузійної передопераційної терапії, корекції водно-електролітного балансу. Найбільш поширеними методами нормалізації товстокишкового пасажу є: відновлення просвіту прямої кишки шляхом ендоскопічної реканалізації і накладення колостоми з лапаротомного доступу або лапароскопічно.

Мета роботи полягала в дослідженні результатів малоінвазивних методів лікування пухлин товстого кишечника, ускладнених кишковою непрохідністю, із застосуванням ендоскопічної реканалізації та стентування.

Період роботи охоплює 2009-2014рр. За цей час госпіталізовано 120 хворих з раком товстого кишеч- ника, ускладненим кишковою непрохідністю. Чоловіків було 50, жінок - 70. Вік перебував у межах від 47 до 95 років. Зі 120 пацієнтів 53 госпіталізовані в декомпенсованій стадії гострої обтураційної кишкової непрохідності, 67 - у стадії компенсованої та субкомпенсованої кишкової непрохідності. У 17 випадках після ендоскопічної реканалізації вдалося провести під контролем ендоскопа двопросвітний зонд через зону обтурації з подальшим відмиванням калових мас. У 5 випадках вдалося провести стент через обтурацію. Після стихання явищ непрохідності хворі були оперовані через 2-4 доби після інтенсивної передопераційної підготовки.

Ендоскопічну комбіновану реканалізацію товстої кишки проводили із застосуванням монополярної діатермокоагуляції, високоенергетичного лазера i фіброколоноскопа GF-301 Olympus (Японія). На першому етапі цим пацієнтам відновлення просвіту товстої кишки виконували методом монополярної діатермокоагуляції, формуючи канал за допомогою ендоскопічних інструментів у стенозованій ділянці. Подальше відновлення просвіту товстої кишки поєднували із застосуванням лазерної фотодеструкції пухлинної тканини, чергуючи сеанси реканалізації 3 24-годинною паузою для відторгнення некротизованих фрагментів новоутворення. Обов' язковим компонентом при виборі методу операційного втручання були КТ органів черевної порожнини, МРТ, УЗДорганів черевної порожнини з метою визначення метастатичного ураження парієтальної і вісцеральної очеревин, паренхіматозних органів, локальної поширеності новоутворення. Отримані дані, безумовно, впливали на вибір подальшої тактики лікування пацієнта. Після відновлення пасажу кишкового вмісту створювалася можливість виконання як лапаротомних, так 
i лапароскопічних операцій з урахуванням сучасних онкологічних протоколів.

Лапароскопічні операції виконували, використовуючи ендохірургічний комплекс (“Olympus”, Японія), набір лапароскопічних інструментів, апарат LIGASURE, а також лапароскопічні зшивальні апарати. Показаннями до накладання колостоми лапароскопічно були розвинення повного пухлинного стенозу і неможливість проведення ендоскопічної реканалізації. Після створення карбоксиперитонеуму (тиск $\mathrm{CO}_{2}=11-12$ мм рт. ст.) в черевну порожнину вводили три троакари діаметром 10 мм: у параумбілікальній ділянці для скошеної оптики, в лівій мезогастральній ділянці для ендоскопічних ножиць або ендоскопічного гачка, у правій клубовій ділянці для введення дисектора. Мобілізацію товстої кишки виконували із застосуванням інструментів та апарата LIGASURE. Після мобілізації ділянки товстої кишки кишкову петлю, захоплену затискачем, виводили на передню черевну стінку і фіксували окремими монофіламентними абсорбуючими швами розміром 4-0, відкривали колостому. Після відновлення пасажу калових мас та проведення корекції водноелектролітного балансу, стабілізації стану хворих, через 7-10 діб більшості хворих проводили повторне операційне лікування. Виконували як лапароскопічні резекції ділянки товстого кишечника з накладенням первинного анастомозу, лапароскопічну мануально асистовану резекцію з накладенням анастомозу, так і традиційні лапаротомні операції з видаленням пухлини та накладенням кишкового анастомозу.

Ми прооперували 120 хворих із кишковою непрохідністю пухлинного генезу. Виконано 90 операцій методом лапаротомії і 30 лапароскопічних операцій: це резекції ділянки кишки з пухлиною і накладенням первинного анастомозу, а також операції типу Гартмана.

Традиційні лапаротомні операції були такими: 24 правосторонніх геміколектомій, 12 лівосторонніх геміколектомій; 44 операції Гартмана, а також у 10 випадках виконано накладення колостоми. Із загальної кількості 90 хворих, оперованих лапаротомно, в 60 випадках були проведені екстрені операції через наростаючі явища непрохідності, клініку перфорації кишки і явища перитоніту. 3 них у 37 проведено резекцію кишки з пухлиною і виведенням колостоми. У 23 випадках, зважаючи на поширений перитоніт при пухлинах сліпої і висхідної кишки, проведено видалення пухлини і накладення ілеостоми.

За допомогою методу комбінованої реканалізації товстої кишки просвіт органа був відновлений, у 30 пацієнтів нормалізований пасаж калових мас. У 5 ви- падках метод доповнений стентуванням кишечника нітиноловими стентами. У подальшому, через 4-5діб, цим хворим виконано лапароскопічні операції з видаленням пухлини і накладенням анастомозу. У 7 випадках спроба комбінованої реканалізаціїпухлинного стенозу прямої кишки не була успішною, оскільки у процесі реканалізації мало місце постійне підтікання калових мас з верхніх відділів товстої кишки і крові з ділянки новоутворення. Цим пацієнтам було виконано лапароскопічну колостомію, причому в трьох випадках іï доповнено методикою “Hand Assistent”. Після стабілізації стану хворих на 5-7 добу їм було виконано лапароскопічну резекцію кишки з пухлиною. У 18 випадках виконано реканалізацію з подальшою одномоментною лапароскопічною резекцією і накладенням анастомозу. Ускладнень і летальності в найближчому післяопераційному періоді у пацієнтів, яким було виконано комбіновану реканалізацію пухлинного стенозу, ендоскопічне стентування з подальшою лапароскопічною резекцією, лапароскопічну колостомію, відзначено не було. При застосуванні лапароскопічної резекції з накладенням первинного анастомозу анастомози накладали циркулярними зшивачами CDH29-33 ETHICON (США).

Хворі після лапароскопічних операцій значно менше (в 1,5 раза) потребували наркотичного знеболювання. Активізація пацієнтів після лапароскопічних операцій наставала на 1-2 добу, тоді як після лапаротомних операцій - на 3-4 добу. Середні строки перебування на ліжку склали після лапароскопічних операцій 5-7 діб, після лапаротомії - 8-10 діб. Кількість ускладнень після лапароскопічних операцій була значно менша. Після лапаротомних операцій відзначено 18 випадків нагноєння операційних ран, 3 випадки післяопераційної пневмонії, і в 2 випадках мала місце неспроможність швів із подальшим розвитком поширеного перитоніту. Після лапароскопічних операцій нагноєнь операційних проколів було 4 випадки, післяопераційних пневмоній -1 випадок. Неспроможність швів відзначена в одному випадку, що було зумовлено тим фактом, що хворого оперували 3 приводу ГКН із різко вираженою анемією і низьким рівнем білка. Після діагностування неспроможності проведено лапаротомію $з$ резекцією місця анастомозу і виведенням проксимального відділу кишечника як колостоми на передню черевну стінку. Післяопераційний період ускладнився розвитком нагноєння післяопераційної рани, пневмонією, ерозивною кровотечею з шлунка і дванадцятипалої кишки. Летальність після лапаротомних операцій відзначено в 5 випадках: у 2 випадках після розвитку неспроможності швів анастомозу і поширеного калового перитоніту; 


\section{ПОВІДОМЛЕННЯ}

у 2 - після гострої серцево-судинної недостатності, зумовленої раніше перенесеним інфарктом міокарда; в одному випадку через виникнення післяопераційної пневмонії. У групі хворих після лапароскопічних операцій летальності не було. Цей факт можна пояснити тим, що лапароскопічні операції проводили у хворих з менш вираженою супутньою патологією. Віддалені результати виживання цих двох груп хворих достовірно не відрізнялися. Проте в групі хворих, оперованих лапаротомним доступом, у 12 випадках утворилися післяопераційні вентральні грижі. У групі хворих, оперованих лапароскопічно, післяопераційних гриж не спостерігали.
Висновки. Ендоскопічна реканалізація товстої кишки і лапароскопічна колостомія, а також ендоскопічне стентування є ефективними способами відновлення пасажу калових мас, що дозволяє застосувати одноетапний і двохетапний методи лікування раку товстої кишки. Лапароскопічні операції дозволяють значно знизити кількість післяопераційних ускладнень, утворення післяопераційних гриж, зменшити операційну травму, скоротити терміни лікування, зменшити потребу у використанні наркотичних анальгетиків. Результати лапаротомних операцій достовірно не відрізняються від результатів лапароскопічних операцій. 